\title{
Water uptake and chemical composition of fresh aerosols generated in open burning of biomass
}

\author{
C. M. Carrico ${ }^{1}$, M. D. Petters ${ }^{1,}$, , S. M. Kreidenweis ${ }^{1}$, A. P. Sullivan ${ }^{1}$, G. R. McMeeking ${ }^{1,{ }^{* *}}$, E. J. T. Levin ${ }^{1}$, \\ G. Engling ${ }^{1, * * *}$, W. C. Malm ${ }^{2}$, and J. L. Collett Jr. ${ }^{1}$ \\ ${ }^{1}$ Department of Atmospheric Science, Colorado State University, Ft. Collins, CO 80523, USA \\ ${ }^{2}$ Cooperative Institute for Research of the Atmosphere/National Park Service, Colorado State University, Ft. Collins, CO \\ 80523, USA \\ *currently at: Department of Marine, Earth, and Atmospheric Sciences, Campus Box 8208, North Carolina State University, \\ Raleigh, NC 27695-8208, USA \\ ** currently at: Center for Atmospheric Science, University of Manchester, Manchester, UK \\ ${ }^{* * * *}$ currently at: Department of Biomedical Engineering and Environmental Sciences, National Tsing Hua University, \\ Hsinchu 300, Taiwan
}

Received: 22 January 2010 - Published in Atmos. Chem. Phys. Discuss.: 9 February 2010

Revised: 20 May 2010 - Accepted: 24 May 2010 - Published: 10 June 2010

\begin{abstract}
As part of the Fire Lab at Missoula Experiments (FLAME) in 2006-2007, we examined hygroscopic properties of particles emitted from open combustion of 33 select biomass fuels. Measurements of humidification growth factors for subsaturated water relative humidity $(\mathrm{RH})$ conditions were made with a hygroscopic tandem differential mobility analyzer (HTDMA) for dry particle sizes of 50, 100 and $250 \mathrm{~nm}$. Results were then fit to a single-parameter model to obtain the hygroscopicity parameter, $\kappa$. Particles in freshly emitted biomass smoke exhibited a wide range of hygroscopicity (individual modes with $0<\kappa<1.0$ ), spanning a range from the hygroscopicity of fresh diesel soot emissions to that of pure inorganic salts commonly found in the ambient aerosol. Smoke aerosols dominated by carbonaceous species typically had a unimodal growth factor with corresponding mean $\kappa=0.1$ (range of $0<\kappa<0.4$ ). Those with a substantial inorganic mass fraction typically separated into less- and more-hygroscopic modes at high $\mathrm{RH}$, the latter with mean $\kappa=0.4$ (range of $0.1<\kappa<1$ ). The bimodal $\kappa$ distributions were indicative of smoke chemical heterogeneity at a single particle size, whereas heterogeneity as a function of size was indicated by typically decreasing $\kappa$ values with increasing dry particle diameters. Hygroscopicity varied strongly
\end{abstract}

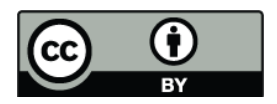

Correspondence to: C. M. Carrico (carrico@lamar.colostate.edu) with biomass fuel type and, to a lesser extent, with combustion conditions. Among the most hygroscopic smokes were those from palmetto, rice straw, and sawgrass, while smoke particles from coniferous species such as spruces, firs, pines, and duffs were among the least hygroscopic. Overall, hygroscopicity decreased with increasing ratios of total carbon to inorganic ions as measured in $\mathrm{PM}_{2.5}$ filter samples. Despite aerosol heterogeneity, reconstructions of $\kappa$ using $\mathrm{PM}_{2.5}$ bulk chemical composition data fell along a 1:1 line with measured ensemble $\kappa$ values.

\section{Introduction}

Open biomass burning is a globally- and regionallyimportant source of greenhouse gases and atmospheric fine particulate matter $\left(\mathrm{PM}_{2.5}\right)$. Deforestation fires, a subset of all burning emissions, have contributed $\sim 19 \%$ of the global postindustrial $\mathrm{CO}_{2}$ radiative forcing (Bowman et al., 2009). Although North American biomass burning emissions represent a relatively small fraction of the global total, it is recognized that they can play a significant role in the degradation of US urban and regional air quality. For example, Spracklen et al. (2007) concluded that summer wildfires were the most important driver of interannual variability in observed total carbonaceous particulate matter (PM) across the continental US. The modeling study of Park et al. (2007) attributed

Published by Copernicus Publications on behalf of the European Geosciences Union. 
$50 \%$ of US annual mean particulate carbon concentrations to biomass burning. Visibility over large regions can be affected by such emissions (McMeeking et al., 2006), and biomass burning PM has been associated with significant impacts on human health (Naeher et al., 2007) and climate on a range of spatial and temporal scales (Ramanathan et al., 2001).

The magnitude of visibility and climate effects is linked, in part, to the hygroscopic properties of the smoke (Kreidenweis et al., 2001), which control water uptake by the particles and depend on the aerosol chemical composition. The mass fractions of various chemical species in accumulation mode smoke aerosols (those most important to light extinction and cloud interactions) are generally apportioned as $\sim 80 \%$ organic carbon, $\sim 12-15 \%$ inorganic compounds, and $\sim 5-8 \%$ black carbon (Reid et al., 2005). Single particle electron microscopy (SEM) shows that these principal components are unevenly distributed over particle size distributions, with tar balls, pure organic particles, organic-inorganic mixed particles, and sooty agglomerates being the principle particle types (Chakrabarty et al., 2006).

As a consequence of the heterogeneity of smoke emissions, the hygroscopic responses of biomass smoke to changing environmental relative humidities (RH) are complex. Environmental SEM observations of individual particles on a filter show that sooty particles do not take up water for $\mathrm{RH}<100 \%$ while the mixed organic/inorganic particles grow hygroscopically, primarily dependent on the inorganic content (Semeniuk et al., 2007). The hygroscopic properties of tar balls are difficult to categorize. Semeniuk et al. (2007) reported small morphology changes at $\mathrm{RH}>60 \%$ but otherwise their data suggested that tar balls from fresh smoke are hydrophobic. In contrast, Hand et al. (2005) showed irreversible dissolution of tar balls at $\mathrm{RH}>83 \%$. The total hygroscopic response of PM generated from fires, as observed by comparing the humidified and dry scattering efficiencies of a population of particles, depends on the fuel and its combustion conditions (Day et al., 2006; Hand et al., 2010).

Particle hygroscopicity and the particle size distribution serve as inputs to models that calculate which particles form cloud drops and which remain as interstitial aerosol in the cloud. Formation of pyrocumulus clouds is supported by the fire-induced convection and simultaneous water vapor emissions from the combustion process. Determining the interstitial fraction of the aerosol is important because those particles are not readily removed by precipitation processes and are thus likely to survive to be injected into the upper troposphere, where they can undergo long-range transport. Reutter et al. (2009) modeled pyrocumulus cloud formation, assuming constant hygroscopicity over the entire size distribution. Although this assumption was clearly inconsistent with current understanding of smoke composition, the authors had little choice because particle size-resolved hygroscopicity inventories for open biomass combustion were not yet available.
In order to address gaps in the current understanding of biomass burning-derived PM interactions with water vapor, we have conducted laboratory investigations of the hygroscopic properties of fresh smoke from open biomass combustion. We examine the importance of fuel type and $\mathrm{PM}_{2.5}$ chemical composition on hygroscopic properties as a function of particle size. Smoke properties undoubtedly evolve after emission as ambient smoke is transported from source regions, ages and mixes with other aerosol types. Fresh smoke emissions, however, are important in source regions and as the starting point for predicting the evolution of smoke properties.

\section{Experimental overview}

The Fire Lab at Missoula Experiments (FLAME 1 and 2) examined the physico-chemical properties of emissions generated in the open combustion of biomass fuels (McMeeking et al., 2009). The studies were conducted in 2006 and 2007 at the U.S. Department of Agriculture/US Forest Service Fire Science Laboratory in Missoula, Montana. We investigated 33 separate fuels and several fuel combinations, with a focus on selecting fuels highly relevant to wildland fire and prescribed burning in the US: montane species (western US); boreal species (northwestern US and Alaska); rangeland species (western US); chaparral species (western US); coastal plain species (southeastern US). We also selected several additional fuels of tropical origin. The origin of and the portion of the plant that was burned (e.g., leaves, needles, or branches) are discussed in more detail in Petters et al. (2009a, b). If a fuel had not dried sufficiently during shipment to readily ignite, it was dried under gentle heating $\left(T<40^{\circ} \mathrm{C}\right)$ for up to 3 days, but the fuels were otherwise left untreated. McMeeking et al. (2009) and Sullivan et al. (2008) present details regarding the classification, moisture content, and $\mathrm{C}$ and $\mathrm{N}$ contents of each fuel, as well as a compilation of gasand particulate-phase emissions from each burn conducted in FLAME 1 and 2.

Fuel masses $(25 \mathrm{~g}<$ mass $<2500 \mathrm{~g}$, typically $\sim 200 \mathrm{~g}$ ) were arranged on a fuel bed platform located in the combustion chamber of the laboratory, which measures approximately $12.5 \mathrm{~m} \times 12.5 \mathrm{~m} \times 22 \mathrm{~m}$ high and has a sampling and exhaust stack exiting through the roof (Christian et al., 2003, 2004). During FLAME 1 (2006), a propane torch was used to ignite the fuel bed, whereas in FLAME 2 (2007) a grid of electrical resistance heaters was placed under the fuel bed which was coated with approximately $15 \mathrm{~g}$ of ethanol and ignited by resistive heating. The ethanol-based ignition method resulted in greater uniformity of ignition and lack of a defined flame front moving through the fuel bed. Two types of experiments were conducted, described as "stack burns" and "chamber burns". Stack burns involved positioning the fuel bed under the stack and actively ventilating emissions with an exhaust fan. During FLAME 2 emissions were sampled from the top 
of the sampling stack through a $0.025 \mathrm{~m}$ OD stainless steel tube to fill a 200 liter stainless steel drum, from which hygroscopicity instruments sampled. During chamber burns (both FLAME 1 and 2), the fuel bed was positioned away from the stack inlet, all vents of the chamber were closed and emissions were sampled directly from the chamber over a two to three hour period (McMeeking et al., 2009).

For most of the burns, the samples were representative of emissions over the entire burn, from ignition until the fuel was consumed. For these burns we report fire-integrated aerosol properties. However, several stack burn experiments sampled only from either the initial or the final phase of combustion (flaming or smoldering), as determined visually; these special conditions are noted when data are presented. Other variations on the basic experimental design used in a few selected experiments included varying the mass of fuel used, combining fuels, and varying the size of fuel elements such as sticks/branches, as discussed further below.

\section{Methods}

Measurements of water sub-saturated aerosol hygroscopic growth were conducted with a hygroscopic tandem differential mobility analyzer (HTDMA, Fig. 1) (Rader and McMurry, 1986), with the particular design of the instrument described in detail in Carrico et al. (2008). The HTDMA measured particle diameter growth factors (GF) as a function of subsaturated relative humidity $(\mathrm{RH}<95 \%)$ (Brechtel and Kreidenweis, 2000; Prenni et al., 2003; Carrico et al., 2005, 2008). The instrument selected a charge neutralized, nearly monodisperse particle population with an electrical mobility classifier; typically, dry diameters of 50, 100 and $250 \mathrm{~nm}$ were selected. Subsequently, this subpopulation was humidity-conditioned before measuring the grown particle sizes with a second classifier interfaced to a condensation particle counter. For the stack burn experiments, measurements were conducted at a single RH set point of $90 \% \pm 2 \%$. For the longer duration chamber burn experiments, eight RH set points were selected over the range of $40 \%<\mathrm{RH}<95 \%$. A sheath to sample flow ratio of 5:1 was used in both classifiers. The HTDMA system was housed in a temperature-controlled enclosed chamber maintained at $25 \pm 0.5^{\circ} \mathrm{C}$ with isothermal conditions maintained within $\pm 0.2^{\circ} \mathrm{C}$ in the second classifier column. Due to laboratory air conditioning limitations during FLAME 1, several experiments were conducted at slightly warmer conditions $\left(<28^{\circ} \mathrm{C}\right)$, although equivalent isothermal conditions were maintained through the instrument. All measurements occurred near surface atmospheric pressure (approximately $885 \mathrm{mbar}$ ). RH in the second classifier column was calculated using dew point temperature measurements from a hygrometer $\left( \pm 0.2^{\circ} \mathrm{C}\right)$ in combination with mean dry bulb temperature from two thermistor probes $\left( \pm 0.2^{\circ} \mathrm{C}\right)$ (Carrico et al., 2008). Additionally, two capacitive sensors measured RH and dry bulb temperature $( \pm 2 \%$ at $\mathrm{RH}=90 \%$ and $\pm 0.2{ }^{\circ} \mathrm{C}$ ) upstream of the second classifier. A least squares regression of $\mathrm{RH}$ at all set points for the hygrometer and thermistor combination vs. the capacitive sensor and thermistor combination gives a slope $=0.99$, a $R^{2}$ value $>0.99$ and an offset of $0.5 \%$ in RH units.

Measured hygroscopic growth factors, $\mathrm{GF}(\mathrm{RH})$, were computed as the ratio of the wet diameter $\left(D_{\mathrm{p}}(\mathrm{RH})\right)$ to the dry particle diameter $D_{\mathrm{d}}$ using the "TDMAFIT" method (Stolzenburg and McMurry, 1988; Zhou et al., 2002), with an estimated uncertainty (one standard deviation) of \pm 0.02 in GF. This uncertainty in sizing includes uncertainty in flow rates and in classifier voltages. Additional uncertainty is introduced due to particle shape factor since the inversions assume spherical particles; this uncertainty is not included in our estimates here. All of the reported GF measurements were taken along the humidification (deliquescence) branch, that is, the particles were initially dry $(\mathrm{RH}<15 \%)$ when sizeselected in the first classifier, and were then exposed to the set point humidity for a residence time of approximately $10 \mathrm{sec}$ before entering the second classifier. In most of the burns, particles were sampled directly from the chamber without additional drying or other processing before size selection. However, the setup for the FLAME 2 stack burns was modified in an effort to collapse nonspherical structures into more spherical particles before size-selecting (Lewis et al., 2009). The polydisperse sample pulled from the stack was first conditioned to high $\mathrm{RH}(\mathrm{RH}>95 \%)$, and then the particles were dried to $\mathrm{RH}<15 \%$ by passing them through a silica gel diffusion drier (Petters et al., 2009b).

An example of raw humidified distributions for two smoke samples is shown in Fig. 2. The Zhou et al. (2002) TDMAFIT algorithm assumes a Gaussian distribution of growth factors and predicts the humidified size distribution by accounting for the instrument transfer function and charging probability. In some cases aerosol growth was not characterized by a single, larger humidified mode that could be assigned a single GF, but rather the chosen dry diameter yielded two subpopulations with different mean diameters after exposure to elevated RH, termed 'more' and "less" hygroscopic modes (Swietlicki et al., 2000). If the peaks were large enough and separated enough, these subpopulations were resolved by TDMAFIT. For each growth factor mode, three fitted parameters, the arithmetic mean diameter GF, the diameter growth dispersion factor, and the number fraction, define the GF probability density function. The growth factor dispersion factor gives a measure of particle chemical heterogeneity at a given size and it is discussed in relation to cloud condensation nucleus activation in Petters et al. (2009a). For burns with multiple modes we also computed the volumeweighted average of the GF for the two modes, which we term the ensemble hygroscopic growth factor (Carrico et al., 2005). The ensemble GF uses the mean GF values from each mode and converts the number fraction in the select mode to volume fraction to determine a volume weighted ensemble growth factor. All GF were also converted to the 


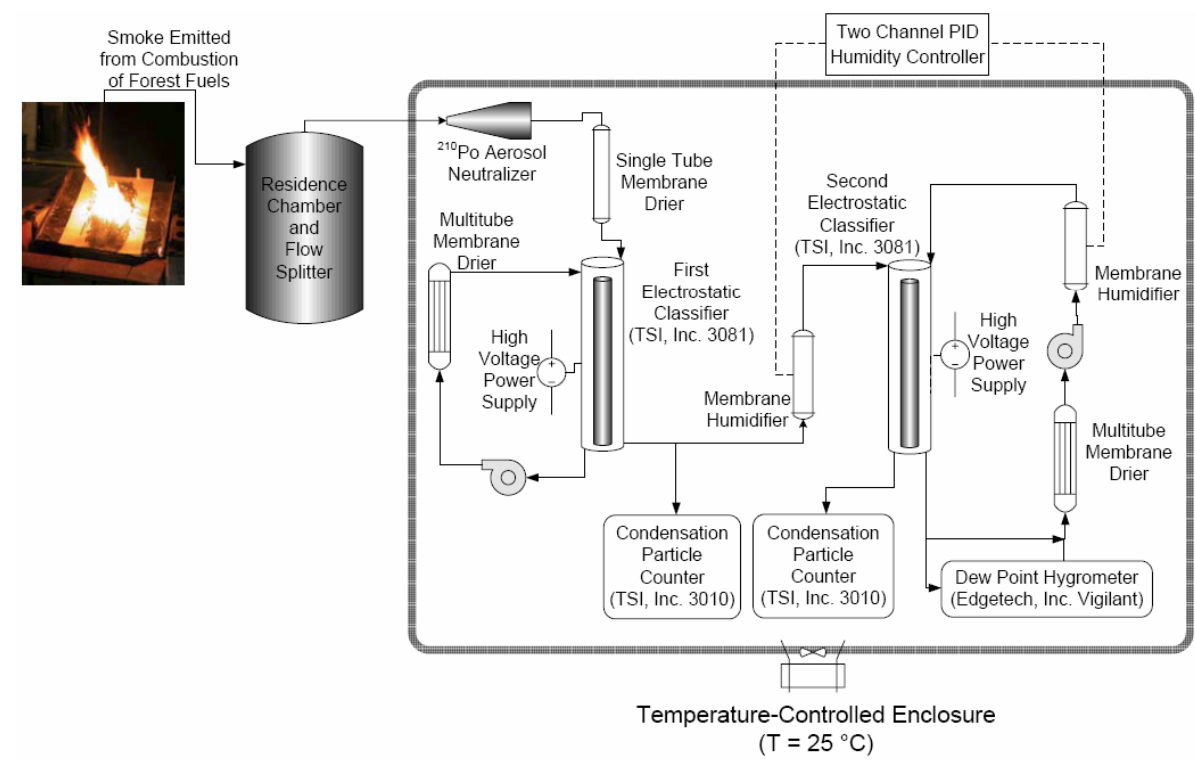

Fig. 1. Schematic of experimental apparatus for smoke aerosol hygroscopicity measurements.

equivalent hygroscopicity parameter, $\kappa$, (Petters and Kreidenweis, 2007) using:

$\kappa=\frac{\left(\mathrm{GF}^{3}-1\right)\left(1-a_{\mathrm{w}}\right)}{a_{\mathrm{w}}}$.

where $a_{w}$ is computed from $R H$ via:

$a_{\mathrm{w}}=\mathrm{RH} / \exp \left(\frac{4 \sigma_{\mathrm{w}} M_{\mathrm{w}}}{\rho_{\mathrm{w}} \mathrm{RTD}_{\mathrm{d}} \mathrm{GF}(\mathrm{RH})}\right)$.

In Eq. (2), $\sigma_{\mathrm{w}}, M_{\mathrm{w}}$ and $\rho_{\mathrm{w}}$ are the surface tension, molecular weight, and density of water, respectively, $T$ is the absolute temperature, and $R$ is the ideal gas constant. The hygroscopicity parameter was computed at $\mathrm{RH}=90 \pm 2 \%$ for all samples. The HTDMA was calibrated using two different salts. Since potassium and chloride have been observed as important components of biomass smoke (Li et al., 2003; Chakrabarty et al., 2006), we measured growth factors of atomized and dried pure potassium chloride aerosol (for $D_{\mathrm{d}}=100 \mathrm{~nm}$ ) for both the deliquescence (increasing RH) and efflorescence (decreasing RH) branches. Our data compared well with calculations that assume spherical dry and wet particles and that use water activity and density data for $\mathrm{KCl}$ (potassium chloride) solutions from the literature (Fig. 3) (Tang, 1997). Over the range $0.85<a_{\mathrm{w}}<0.95$, measured hygroscopicity for pure $\mathrm{KCl}$ was $\kappa=0.99 \pm 0.07(n=12)$. Observed deliquescence and crystallization humidities for $\mathrm{KCl}$ were approximately $\mathrm{RH}=83 \%$ and $52 \%$, respectively, consistent with $84 \%$ and $53 \%$ at $25{ }^{\circ} \mathrm{C}$ reported previously (Tang and Munkelwitz, 1993; Tang, 1980). During the FLAME field studies, frequent HTDMA calibrations were conducted with atomized and dried pure $\left(\mathrm{NH}_{4}\right)_{2} \mathrm{SO}_{4}$ (ammonium sulfate) particles. For 22 measurements performed

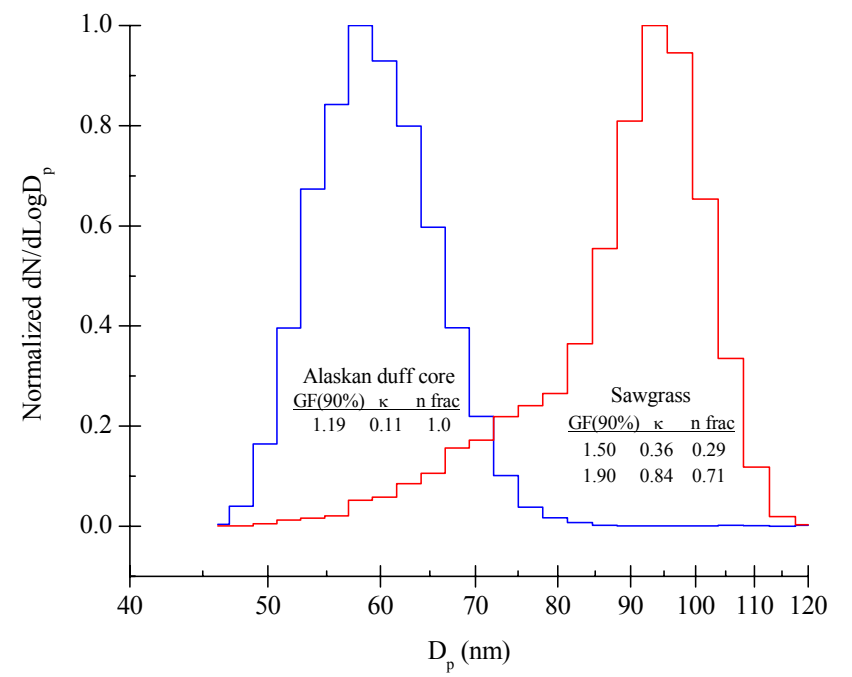

Fig. 2. Example size distributions after humidification, for dry $D_{\mathrm{p}}=50 \mathrm{~nm}$. A unimodal, relatively low hygroscopicity case (Alaskan duff core) is shown in comparison to a strongly hygroscopic and bimodal case (sawgrass). Values tabulated inside each distribution are the derived GF at $90 \% \mathrm{RH}$, the associated $\kappa$ value, and the number fraction of particles assigned to each hygroscopicity mode.

throughout the field study, $\kappa=0.54 \pm 0.06$ at $\mathrm{RH} \sim 90 \%$, agreeing with expected $\kappa=0.55$ (Petters and Kreidenweis, 2007).

Smoke particles were collected onto filters by two IMPROVE sampling systems with $\mathrm{PM}_{2.5}$ and $\mathrm{PM}_{10}$ inlets (chamber burns only). IMPROVE filter samples were analyzed for inorganic ions using ion chromatography, for 


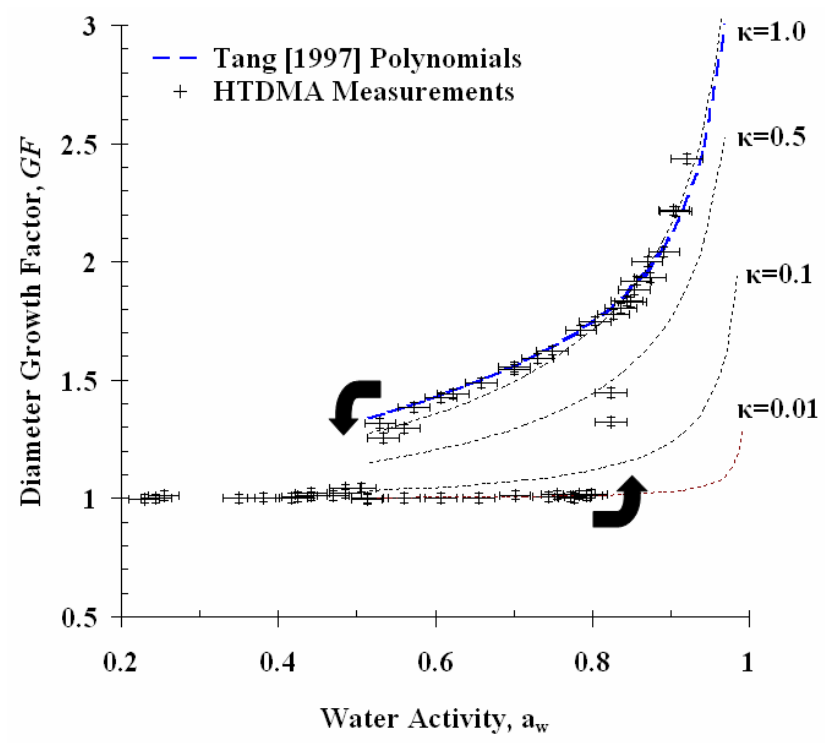

Fig. 3. Comparison of HTDMA-measured growth curves with theory for pure $\mathrm{KCl}$ particles with $D_{\mathrm{d}}=100 \mathrm{~nm}$. Both deliquescence and efflorescence branches were measured, as shown by the heavy black arrows. Estimated uncertainties in the measurements are shown as error bars. Predicted $\mathrm{GF}(\mathrm{RH})$ curves for various assumed values of the hygroscopicity parameter, $\kappa$, are also shown.

organic and elemental carbon using the Transmission Optical Reflectance technique (Chow et al., 1993), and for elemental composition using x-ray fluorescence (Malm et al., 2004). Appropriate values of $\kappa$ and density $(\rho)$ for individual chemical components identified by these methods are given in Table 1, and four categories of compounds are considered as listed at the end of Table 1. For the purposes of calculating $\kappa$ from composition data, inorganic ions are the sum of the individual salts listed in Table 1. Organic mass is found from OC multiplied by 1.55 to account for non-carbon constituents of the organic species (Levin et al., 2010). Dust species are calculated from the sum of $\mathrm{CaO}$ and $\mathrm{Al}_{2} \mathrm{O}_{3}$ from calcium and aluminum determined from $\mathrm{x}$-ray fluorescence obtained from IMPROVE protocols. A full description of the compsition measurements, analytical methods, and results is found in McMeeking et al. (2009) and Sullivan et al. (2008), and the assumptions used to reconstruct smoke chemical composition are discussed in Levin et al. (2010).

\section{Results}

\subsection{Hygroscopic diameter growth factors}

HTDMA-measured, ensemble-averaged hygroscopic diameter growth factors for $100 \mathrm{~nm}$ particles measured in FLAME $1(n=16)$ and FLAME $2(n=18)$ chamber burns are shown in Fig. 4. We removed the Kelvin effect for all data using Eq. (2) and present growth factors as a function of $a_{w}$. Gen-
Table 1. Values of hygroscopic parameter $\kappa$ and dry bulk density $\rho$ for compounds relevant to biomass smoke and used to approximate values for four composition categories listed as the end of Table 1. Unless noted, $\kappa$ values are from Petters and Kreidenweis (2007) and densities from Lide (2005).

\begin{tabular}{|c|c|c|c|}
\hline Species & $\kappa$ & $\rho$ & Reference \\
\hline $\mathrm{KCl}$ & 0.99 & 1.99 & This work \\
\hline $\mathrm{K}_{2} \mathrm{SO}_{4}$ & 0.52 & 2.66 & (Kelly and Wexler, 2006) \\
\hline $\mathrm{KNO}_{3}$ & 0.93 & 2.11 & (Kelly et al., 2008) \\
\hline $\mathrm{NH}_{4} \mathrm{Cl}$ & 1.01 & 1.53 & \\
\hline$\left(\mathrm{NH}_{4}\right)_{2} \mathrm{SO}_{4}$ & 0.53 & 1.76 & \\
\hline $\mathrm{NaCl}$ & 1.12 & 2.16 & \\
\hline $\mathrm{Na}_{2} \mathrm{SO}_{4}$ & 0.68 & 2.68 & \\
\hline $\mathrm{Al}_{2} \mathrm{O}_{3}$ & 0 & 3.97 & \\
\hline $\mathrm{CaO}$ & 0 & 3.3 & \\
\hline $\mathrm{EC}$ & 0 & 1.8 & (Bond and Bergstrom, 2006) \\
\hline organic acids & 0.2 & $1.4-1.9$ & \\
\hline HULIS & 0.05 & 1.5 & \\
\hline levoglucosan & 0.165 & 1.64 & \\
\hline Composition Category & & & \\
\hline inorganic salts & 1 & 1.5 & \\
\hline organic carbon & 0.03 & 1 & \\
\hline dust & 0 & 3 & \\
\hline elemental carbon & 0 & 1.8 & \\
\hline
\end{tabular}

erally, measurable water uptake $(\mathrm{GF}>1.02)$ occurred for water activity $a_{\mathrm{w}}>0.4$. For the RH scans in Fig. 4, ensemble GF measured at $a_{\mathrm{w}}=0.9$ ranged from $1.04<\mathrm{GF}<1.70$, corresponding to a $\kappa$ range of $0.02<\kappa<0.55$. For $a_{\mathrm{w}}>$ 0.7 , deliquescence-type behavior occurred for some samples (e.g., palmetto smoke in both studies), and the highest observed GF curves approached those of pure salts such as ammonium sulfate often found in atmospheric aerosols ( $\mathrm{Ta}-$ ble 1).

The most hygroscopic particles included those emitted from the combustion of Asian rice straw, palmetto, sugarcane, sagebrush, and black needlerush, while the least hygroscopic smoke was derived from the combustion of (powdered) lignin, a biopolymer found in many plants. Many of the particles produced in the combustion of montane and boreal fuels, including the pines, firs, duffs, and spruces, demonstrated relatively low hygroscopicity $(\kappa \sim 0.1)$. Combustion of these fuels was typically dominated by the smoldering phase, producing an aerosol having a large mass fraction of organic carbon (McMeeking et al., 2009). Particles emitted from combusting Western US rangeland species and chaparral, with the exception of manzanita, generally had larger $\kappa$ values than did those from conifers and duffs. These burns had a strongly flaming phase, likely supporting the emission of more inorganic material at the higher temperatures achieved during the combustion. Particles produced in combustion of the Southeastern US coastal plain and tropical fuels had the widest variance in ensemble-mean hygroscopic response, spanning the approximate range of $0.05<\kappa<0.6$. However, these groupings of fuels encompassed a broad 

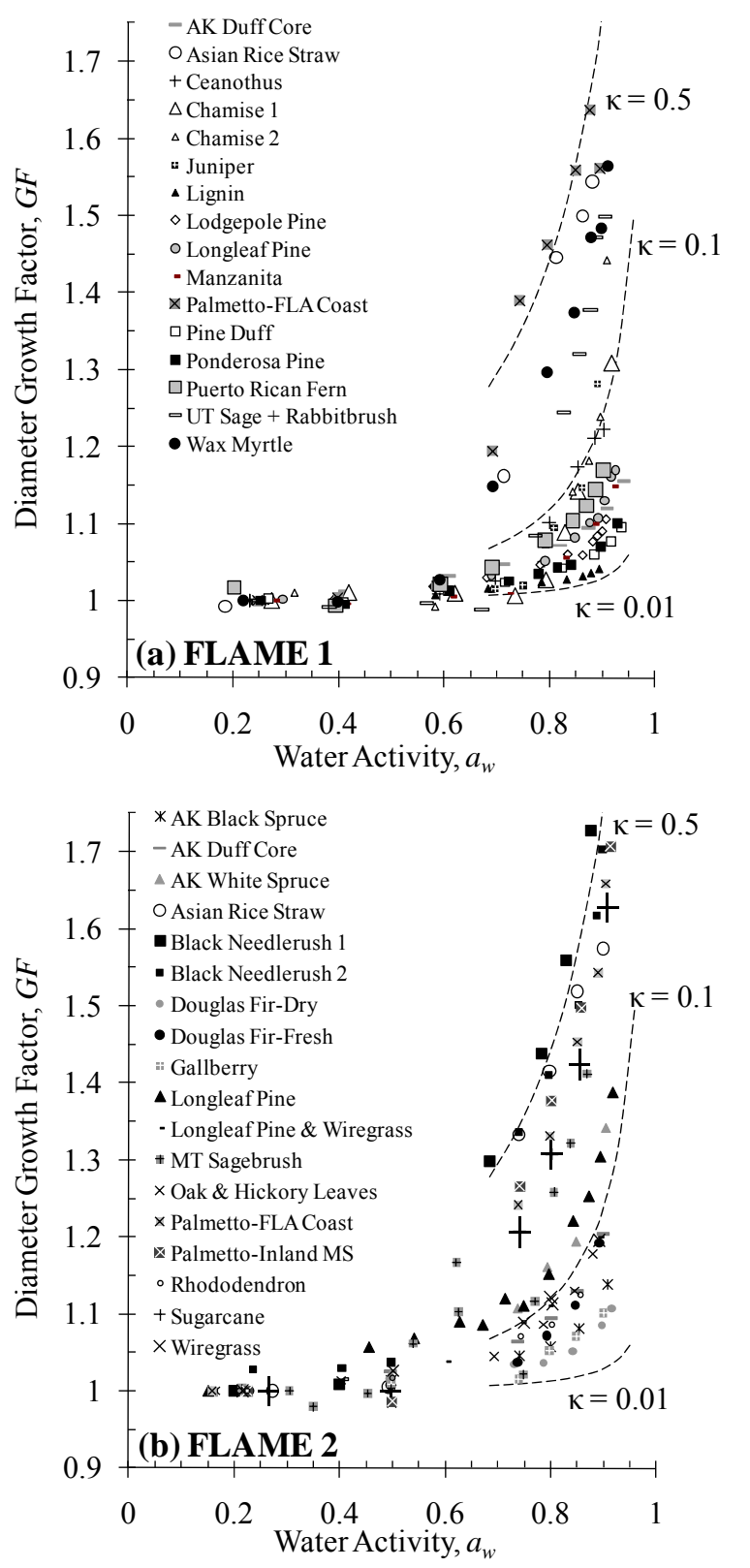

Fig. 4. Compilation of chamber burn ensemble GF as a function of $a_{\mathrm{w}}$ for $D_{\mathrm{d}}=100 \mathrm{~nm}$ particles during (a) FLAME 1 and (b) FLAME 2. Error bars indicating the estimated uncertainties of the measurement are shown in panel (b) for sugarcane. (AK=Alaska, FLA=Florida, MS=Mississippi, MT=Montana,UT=Utah).

range of plant types, including coniferous trees (e.g., long leaf pine), deciduous trees (e.g., oak and hickory), grasses (e.g., sawgrass), and agricultural waste (e.g., Asian rice straw). The connection between fuel type and its combustion conditions, described in detail in Hopkins et al. (2007), ultimately relates to the hygroscopicity of the smoke which is explored in more detail below.

\subsection{Chemical heterogeneity and smoke hygroscopicity}

Many of the smoke samples were externally mixed aerosols, as apparent from the presence of multiple growth modes. Figure 5 shows results for a common set of stack burns from FLAME 2, for three dry diameters, $D_{\mathrm{d}}=50,100$, and $250 \mathrm{~nm}$ (Fig. 5a, b, and c, respectively). The $\kappa$ representative of each distinct mode, as determined by TDMAFIT, is plotted on the X-axis, with the areas of the bubbles proportional to the number fraction in each mode. All of the burns had some proportion of particles with $0<\kappa<0.4$, often the dominant number fraction. Approximately half of the burns yielded aerosols with bimodal growth distributions for the selected dry sizes, indicative of chemical heterogeneity among particles of the selected dry size. For these cases, a second more hygroscopic mode having $0.1<\kappa<1.0$ was observed in addition to the less hygroscopic mode. Comparisons of $\kappa$ values for $D_{\mathrm{d}}=50,100$, and $250 \mathrm{~nm}$ particles show that this chemical heterogeneity was a function of particle size. Generally, the number fraction of particles in the more hygroscopic mode increased with decreasing particle size. For example, $250 \mathrm{~nm}$ particles emitted in the Asian charcoal burns (the uppermost case on all panels) were characterized by a single hygroscopicity $0.1<\kappa<0.2$. A second more hygroscopic mode with $0.6<\kappa<0.9$ emerged for $100 \mathrm{~nm}$ and $50 \mathrm{~nm}$ particles, with the $50 \mathrm{~nm}$ particle number concentrations dominated by the more-hygroscopic particles.

\subsection{Impacts of combustion conditions and fuels on hygroscopicity}

A summary of the observed hygroscopicities of smoke generated by the combustion of ponderosa pine for controlled combustion conditions is shown in Fig. 6a-c. Experiments included propagation of the flame front uphill (heading fires) and downhill (backing fires), selecting emissions from only the flaming or smoldering phases, fuel mass scaling experiments $(80 \mathrm{~g}<$ initial dry fuel mass $<2500 \mathrm{~g})$, continuously feeding fuel to the fire, and selectively combusting wood or needle fuel components. In order to create heading or backing conditions, the fuel bed was angled upward and the fire started at the bottom or top of the fuel bed, respectively. A relatively narrow range in $\kappa$ was observed despite the large variety of tested conditions. The largest excursions in $\kappa$ were related to dry particle size, as smaller particles were generally more hygroscopic. For all particle sizes and all ponderosa pine burns, a less-hygroscopic mode dominated, with hygroscopicity in the range $0<\kappa<0.17$. A notable difference in comparing burns of ponderosa pine was a small number fraction of hygroscopic particles with $0.4<\kappa<0.6$ observed in the backing burns for $D_{\mathrm{p}}=50 \mathrm{~nm}$ particles and less strongly for $D_{\mathrm{p}}=100 \mathrm{~nm}$. The large $\kappa$ values indicate the presence of inorganic compounds. These burns featured a slower, more continuous flame front propagating downhill, 


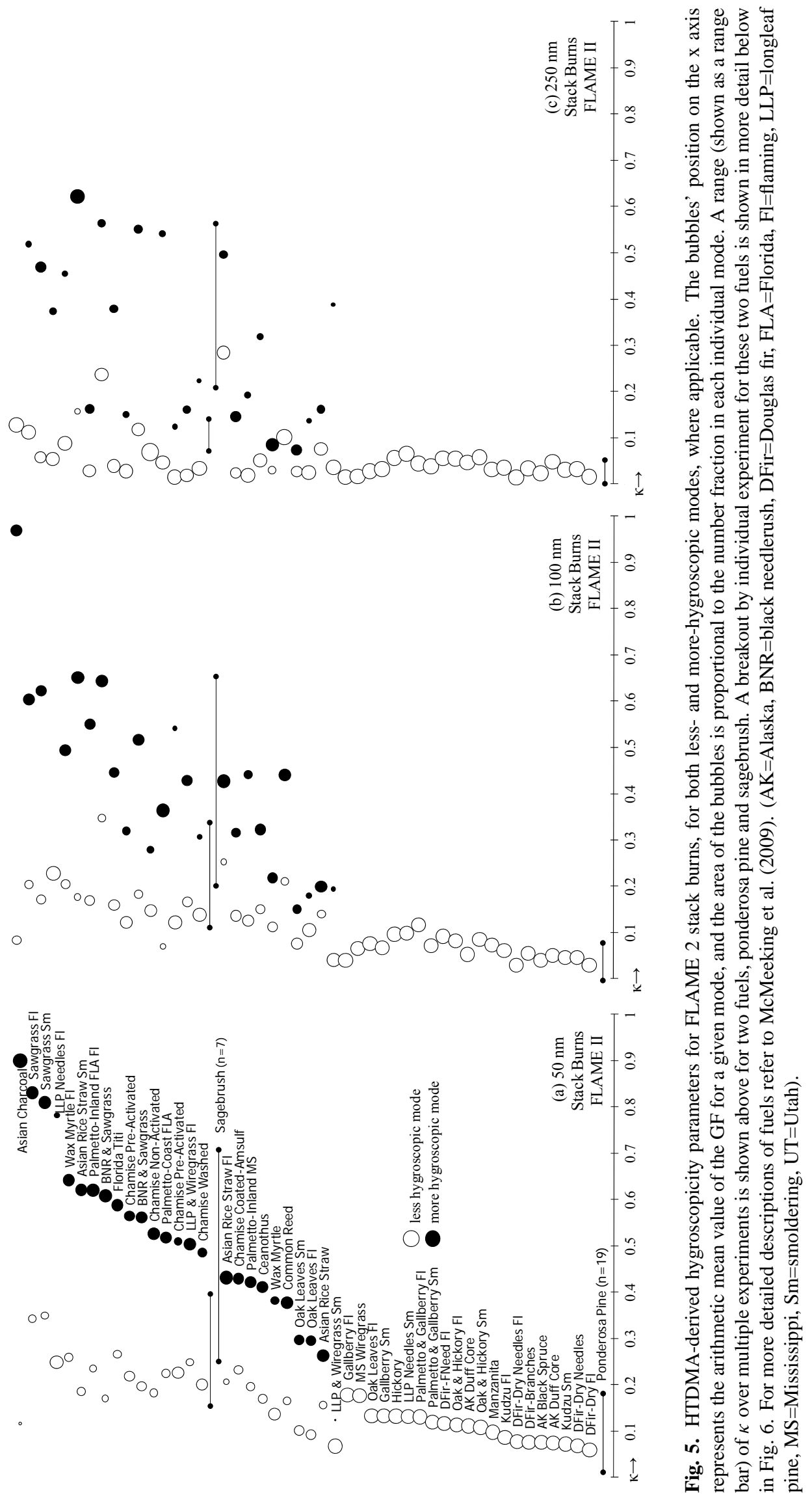



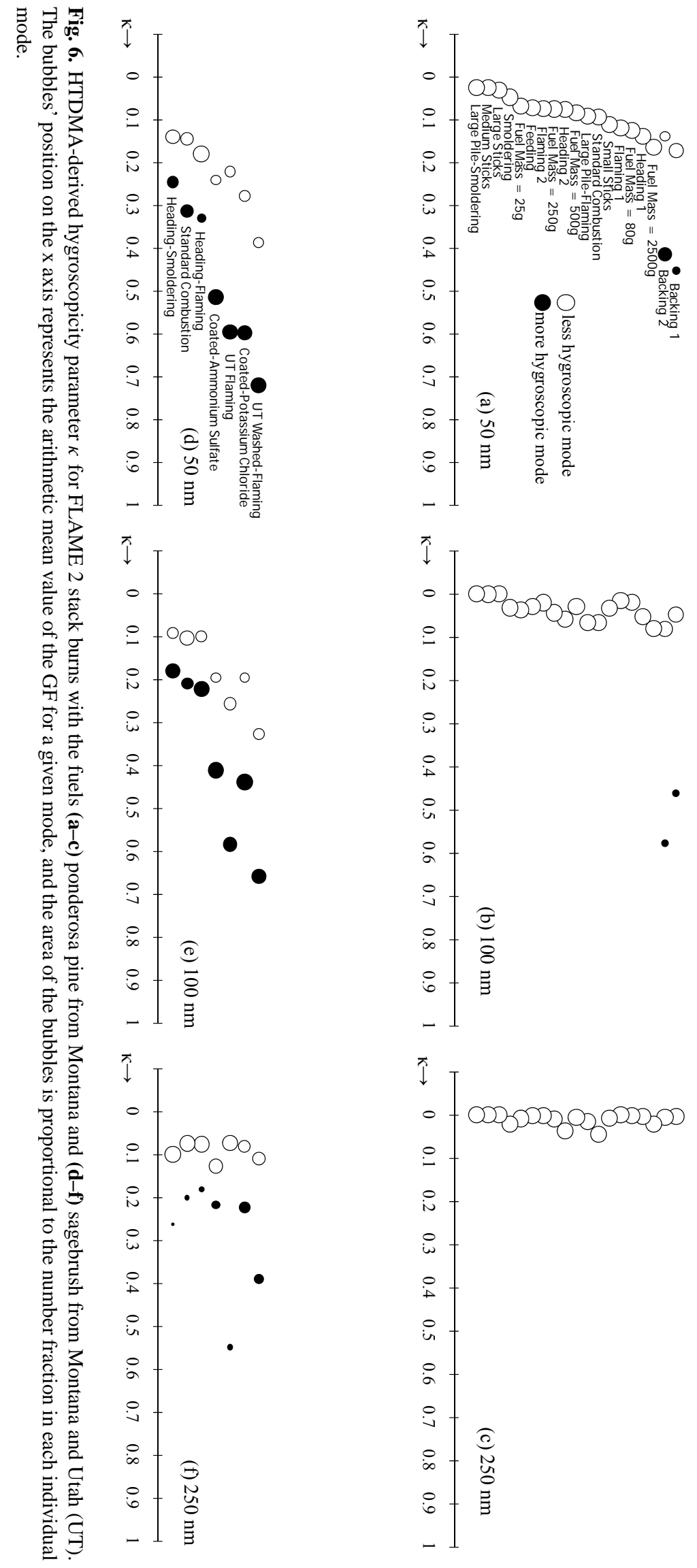
and these burn conditions may have resulted in less internal mixing of emitted species.

A comparison among burns with Montana sagebrush is shown in Fig. 6d-f. Sagebrush experiments included a standard combustion burn, heading burns with flaming and smoldering conditions, and experiments where the fuel was precoated with a solution of $\left(\mathrm{NH}_{4}\right)_{2} \mathrm{SO}_{4}$ or $\mathrm{KCl}$. Two experiments used sagebrush from a second location near Salt Lake City, Utah, and it was burned under flaming conditions, with and without pre-washing the fuel with deionized water. The pre-washing and pre-coating experiments, and the collection of the same fuel from two locations, were designed to help clarify whether inorganic species present in the smoke originated from pollutant species deposited to the plant surface before it was collected, or if they were present in the fuel matrix itself and thus might depend on growing conditions and location. Despite the wide range of parameters tested in these sensitivity experiments, similar bimodal $\kappa$ distributions were found for all experiments, with less $(0.14<\kappa<0.39)$ and more hygroscopic modes $(0.25<\kappa<0.72)$. Kappa for particles emitted from Utah sagebrush had a dominant, morehygroscopic mode with $\kappa=0.6$, compared with $\kappa \sim 0.2-0.3$ for the more-hygroscopic mode of the uncoated Montana sagebrush. These observations suggest a possible importance to emitted PM composition based on fuel source location, which in turn may be related to soil composition (Petters et al., 2009a).

The results in Fig. 6d-f also suggest that atmospheric deposition of hygroscopic salts onto the plants is not an important influence on smoke hygroscopicity. Although we observe some enhancement in hygroscopicity with coating the fuels with salt solutions as observed in Fig. 6d-f, we do not observe a decrease in hygroscopicity with washing the fuels as would happen with washing away surface deposited hygroscopic salts. Similarly, as shown previously in Fig. 5, the fuel chamise showed little systematic difference between experiments with washed and salt-coated fuels. The differences between washed and unwashed fuels' smoke for a given size are similar to the experiment to experiment variability in smoke hygroscopicity with a given fuel as shown in Figs. 5 and 6. Based on the relatively narrow range of hygroscopic response with the variation in combustion conditions as seen in Fig. 6 vs. the wide range shown in Fig. 5 as a function of fuel type, our experiments suggest that the fuel combusted is the more important determinant of smoke hygroscopic response. Although not shown here, we also examined the impact of modified combustion efficiency on hygroscopicity and observed little quantitative relationship between the two.

\subsection{Hygroscopicity of fresh biomass smoke vs. $\mathrm{PM}_{2.5}$ composition}

$\mathrm{PM}_{2.5}$ composition measurements for FLAME 1 and 2 chamber burns (Levin et al., 2010) from IMPROVE filter based samplers were used to calculate the ratio of total carbon $(\mathrm{TC}=$ organic carbon + elemental carbon, using no organic carbon multiplier) mass concentrations to the summed mass concentrations of inorganic ions (INO). The ensemble $\kappa$ value for $100 \mathrm{~nm}$ particles for FLAME 1 and 2 chamber burns is plotted versus this ratio in Fig. 7, which clearly indicates an inverse relationship between these two quantities. Some samples had TC/INO $<1$, including those formed in the combustion of palmetto and Asian rice straw smokes, and these were associated with large $\kappa$ values $(0.4<\kappa<0.5)$. For TC/INO $>20$ (highly carbon-dominated aerosol), $0.02<$ $\kappa<0.08$ was observed. All of these carbon-dominated smokes $(\mathrm{TC} / \mathrm{INO}>20)$ were unimodal in their hygroscopic responses, indicating internal mixing. We suggest that $\kappa$ for the carbonaceous component of fresh biomass burning aerosol can be approximated from the mean and standard deviation of these cases, $\kappa=0.04 \pm 0.02$.

Since direct measurements of $\kappa$ via HTDMA are typically not feasible in many studies, particularly in long-term monitoring programs, we explored whether $\kappa$ could be computed from speciated filter-based mass measurements using simplified assumptions about the aerosol composition. We reconstructed aerosol hygroscopicity assuming only four chemical constituent categories: inorganic species, organic carbon, elemental carbon, and dust / soil, as derived from IMPROVE filter based chemical composition measurements (protocols described in http://vista.cira.colostate.edu/improve/ and in Levin et al., 2010). The assumed $\kappa$ and $\rho$ values for each of these 4 constituents were guided by those of the individual species in the reconstructed mass calculation, as shown in Table 1, and together with mass fractions of each constituent based on composition, were used to reconstruct $\kappa$ of the mixture assuming volume additivity (Petters and Kreidenweis, 2007). Predictions of $\kappa$ from $\mathrm{PM}_{2.5}$ chemical composition for FLAME 1 and 2 chamber burns are compared with HTDMA measured ensemble $\kappa$ for $D_{\mathrm{d}}=100 \mathrm{~nm}$ particles in Fig. 8. An ordinary least-squares regression gives a slope $=0.89$, intercept $=0.03$, and $R^{2}=0.62$ for the regression of measured vs. calculated $\kappa$. Overall, 26 out of 32 data points are within a factor of 2 in $\kappa$ envelope shown in Fig. 8. Based on estimated uncertainties in measured GF and $a_{\mathrm{w}}$, error bars for measured $\kappa$ are shown in Fig. 8. With these uncertainty bars, 19 of 32 data points overlap the 1:1 line. Despite the aerosol heterogeneity previously discussed and the simplified 4-component model used for the reconstructions, measured and predicted $\kappa$ were in reasonable agreement as shown in Fig. 8.

\subsection{Comparison of smoke and plant extract hygroscopic properties}

Following the approach in studies of hygroscopicity of laboratory filter extractions of smoke samples (Carrico et al., 2008), we investigated the water uptake properties of aqueous extracts of several unburned fuels. We created particles 


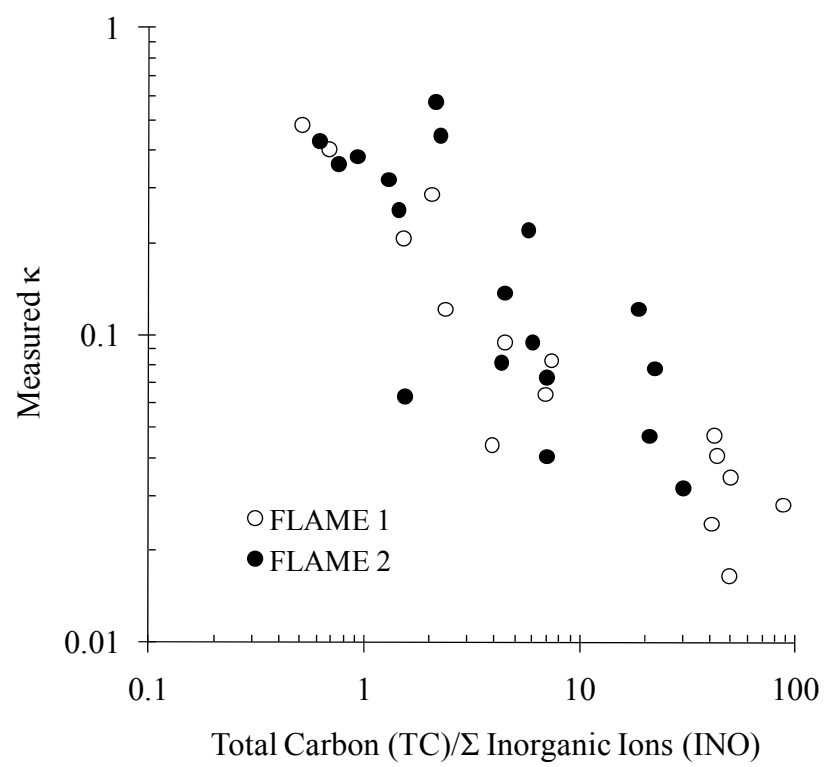

Fig. 7. HTDMA-derived hygroscopicity parameter $\kappa$ measured for $100 \mathrm{~nm}$ dry diameter particles vs. the ratio of total carbon $(\mathrm{EC}+\mathrm{OC})$ mass concentration to the sum of the mass concentration of inorganic ions (INO). Composition data were computed from IMPROVE data as discussed in the text. Data are shown for each FLAME 1 and FLAME 2 chamber burn that has available composition data.

from the aqueous extracts of three fuels used in FLAME 2: Alaskan duff core, Asian rice straw, and coastal Florida palmetto. The extraction process involved two $15 \mathrm{~min}$ sonications of the fuels in ultrapure water. This was followed by aerosolization of the extracts using a constant output atomizer, and drying of the resulting droplets to produce residue particles.

The measured GF of the extract-derived particles were remarkably similar to the GF obtained for the emitted combustion particles for that fuel during the FLAME 2 study (Fig. 9). Alaskan duff core smoke was dominated by organic carbon species (approximately 95\% by mass) (Levin et al., 2010) and both the smoke and the aqueous extract particles were only weakly hygroscopic. The low $\kappa$ for the duff core samples suggests that some water-soluble organic species, with relatively small $\kappa$, were present in both the fuel itself and in the smoke that it produced. Contrastingly, Florida palmetto and Asian rice straw smoke both consisted of approximately $50 \%$ inorganic species by mass (Levin et al., 2010) with secondary contributions from elemental carbon (31\%) for palmetto and organic carbon $(40 \%)$ for Asian rice straw. The palmetto and rice straw samples consistently show strong hygroscopic growth in both in situ smoke and the aqueous fuel extract, suggestive of the presence of hygroscopic salts since most organic species have lower $\kappa$ than observed in either the extracts or the smoke (Table 1).

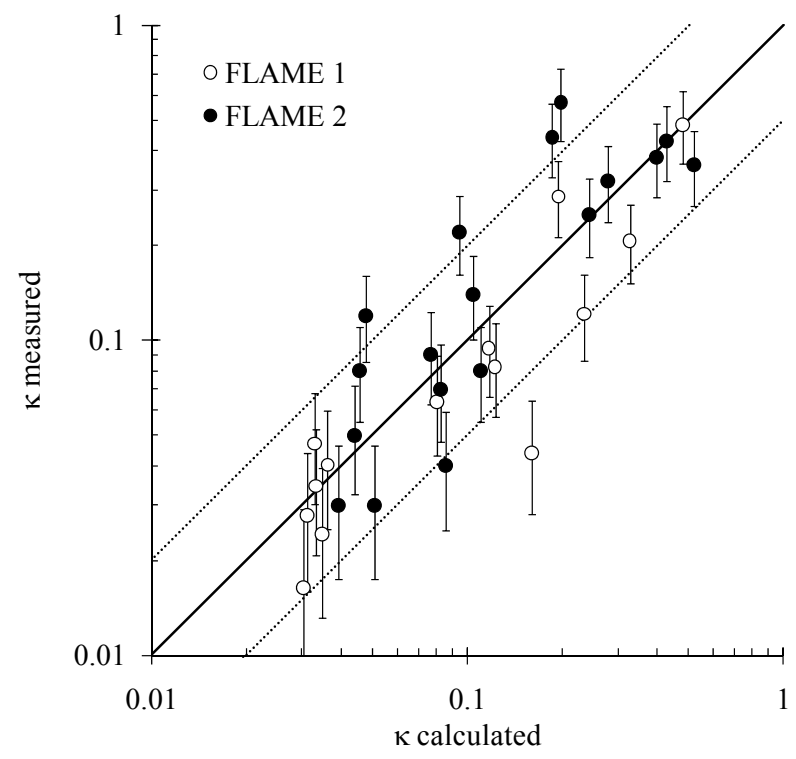

Fig. 8. Comparison of HTDMA-derived ensemble $\kappa$ with $\kappa$ values calculated from $\mathrm{PM}_{2.5}$ chemical composition from IMPROVE filter samples for FLAME1 and 2 chamber burns. The solid line is 1:1 and the dashed lines represent \pm a factor of 2 .

The hygroscopicity data for the water extracts, together with the correspondence seen between ionic species content and hygroscopicity, suggest that the water-soluble composition of the biomass fuel is likely to play a role in determining the hygroscopicity of the resultant smoke from its combustion. Based on our studies, the relative fractions of inorganic vs. carbonaceous material in the aerosol are the primary driver of smoke hygroscopicity. Furthermore, laboratory evidence from several studies has shown that the oxidation process with certain organic carbon compounds only modestly increases the hygroscopic response (Petters et al., 2006; George et al., 2007, 2008, 2009). A more comprehensive study with many fuels and integrating chemical analyses of both the smoke and fuel extracts would be necessary to attribute a more general relationship between fuel and smoke properties.

\section{Discussion and conclusion}

We report measurements of fresh biomass smoke hygroscopic growth and related chemical properties from the FLAME laboratory experiments at the USDA/USFS Fire Science Laboratory in Missoula, MT. Fresh biomass smoke hygroscopic response for size-selected particles ranged from almost hydrophobic $(\kappa \sim 0)$ to as hygroscopic as pure inorganic salts such as ammonium sulfate and sodium chloride $(\kappa \sim 1)$. Using a $\kappa$-mixing model and simplified descriptions of smoke composition, the smoke hygroscopicities predicted from bulk $\mathrm{PM}_{2.5}$ composition data were broadly consistent 


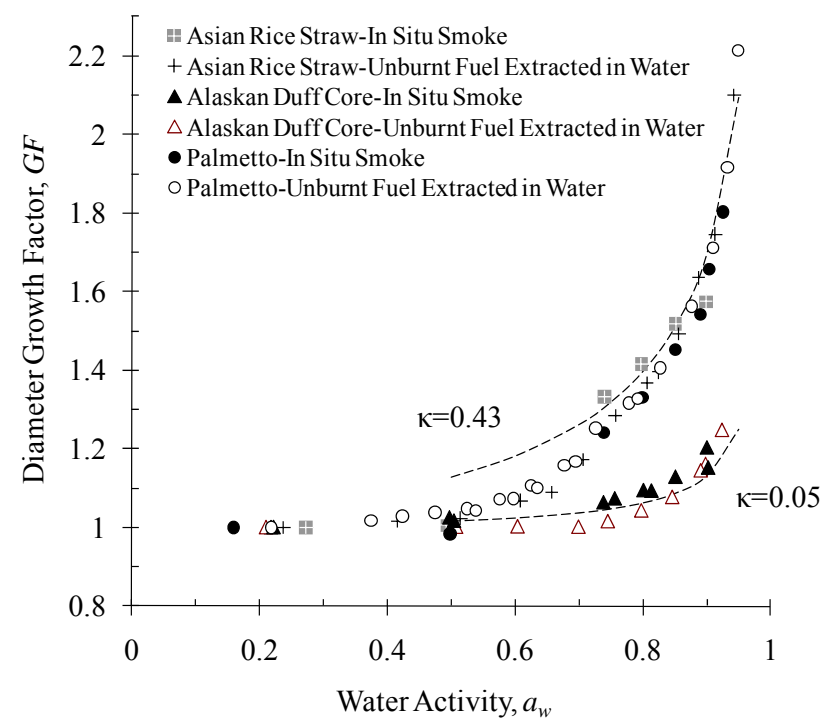

Fig. 9. HTDMA-measured ensemble hygroscopic growth curves for in-situ smoke particles and for particles generated from aqueous extracts of unburned fuels, for three biomass fuels. In all cases, $D_{\mathrm{d}}=100 \mathrm{~nm}$.

with measured values. Variability in chemical composition as a function of particle size is one likely contributor to discrepancies between measured $\kappa$ and those calculated from bulk $\mathrm{PM}_{2.5}$ chemical composition.

Biomass fuel characteristics, as well as the combustion conditions (flaming or smoldering), were of great importance to the hygroscopic properties of the smoke. Overall, pines, duffs, firs, and woods produced the least hygroscopic smoke aerosols, while several chaparral species, grasses, and tropical fuels such as palmetto and rice straw produced the most hygroscopic smoke. We reiterate that our results apply to freshly emitted biomass burning aerosols, which is only one important subset of all ambient aerosols. However, our findings are consistent with field observations reported in the literature. For example, ambient measurements of biomass smoke from the chaparral region of Southern California were also indicative of strong hygroscopicity, at times exceeding $\kappa=0.6$ (Cocker et al., 2001). Ambient aerosol sampled during the Yosemite Aerosol Characterization Study (YACS) study was often impacted by aged smoke from coniferous forest fires in the Northwest US and secondary organic aerosol $\left(\sim 70 \%\right.$ of average $\mathrm{PM}_{2.5}$ mass was carbonaceous) (McMeeking et al., 2006; Engling et al., 2006). During YACS, hygroscopicity ranged between $0.10<\kappa<0.32\left(D_{\mathrm{d}}=100 \mathrm{~nm}\right)$, and was lowest during periods with the highest smoke influence (Carrico et al., 2005; Malm et al., 2005). The FLAME $\kappa$ values for fresh pine and duff smokes $(0.02<\kappa<0.14)$ overlap the lower end of this range. Dinar et al. (2007) report hygroscopicity ranging from $0.07<\kappa<0.10$ for extracts of humic-like substances from biomass burning samples, with larger values corresponding to more aged aerosols. These values compare to the least hygroscopic smokes we found in this study, i.e. those that contain the highest fractions of carbonaceous material.

Generally, the number of hygroscopic modes and their respective $\kappa$ values were similar among varying burns of a given fuel in the FLAME studies. Smoke chemical composition clearly drives its hygroscopic response. Smokes with total carbon contributions exceeding $90 \%$ of $\mathrm{PM}_{2.5}$ mass were all weakly hygroscopic and unimodal with $\kappa<0.1$, while the most hygroscopic smokes were those that had substantial contributions from inorganic species. These observations indicate that inorganic species were primary determinants of smoke hygroscopicity, and the overall ratio of total carbon to measured inorganic ionic mass was inversely related to smoke hygroscopicity. The importance of inorganic components in driving ambient aerosol hygroscopicity has been found in previous studies of ambient smoke-impacted aerosols in North America (Carrico et al., 2005) and Africa (Semeniuk et al., 2007). Also, several laboratory studies of mixtures have found little influence of the speciation or functionality of organic species in affecting the hygroscopicity when mixed with inorganics (Garland et al., 2007; Moore and Raymond, 2008). The general consistency of the fresh smoke properties reported here with ambient observations is important as it suggests that smoke hygroscopicity may be modeled with some general relationships to fuels, combustion conditions, and the smoke inorganic-to-organic composition ratio.

Many smokes demonstrated heterogeneity in terms of external mixing, evident from the separation of growth modes into more and less hygroscopic populations at higher relative humidity. Ambient studies of aerosols with strong smoke influences in the western US and the Amazon have demonstrated the occurrence of bimodal profiles (Carrico et al., 2005; Rissler et al., 2006). Here our findings show that some fresh biomass smokes are emitted (or develop very soon after emission) a bimodal hygroscopic response, before mixing with aerosols from other sources.

It is generally accepted that different species are emitted during the flaming and smoldering phases of combustion, and thus combustion temperature and efficiency should exert a strong influence on smoke aerosol hygroscopicity. Our results suggest that the composition of the fuel also plays a substantial role, as also observed by Hopkins et al. (2007). Those authors observed variations in optical properties (specifically, absorption) related to changes in the graphitic nature of the emitted carbonaceous particles, but some fuels that burned with a strongly flaming phase did not produce particles with a high graphitic content. The presence of inorganic salts in the fuel matrix, and their emission at high temperatures, seem to also play a role. In part, the chemical composition of the fuel relates to natural adaptations of plant species to environmental stresses. Coniferous species are known for producing resins used for wounds and insect 
defense (Lerdau et al., 1994). Additionally, many plants control osmotic pressure by varying solute concentrations in their tissues as a means of regulating hydraulic flow and thus as a drought tolerance mechanism (Kozlowski and Pallardy, 2002). For a small subset of tested fuels in our study, the hygroscopic response of the smoke was similar to that of the particles generated from aqueous extracts of the fuel itself. Chemical similarity of plant tissues and smoke produced has been noted previously. For example, a study of species specific biomass tracers found unaltered and partially altered biomass compounds (such as diterpenoids from conifers) in the smoke, resulting from volatilization/condensation and pyrolysis, respectively (Simoneit et al., 1993).

The type of fuel, combustion phase, smoke chemical composition and resultant aerosol hygroscopic properties are intricately linked. Moreover, combustion products likely also depend on fuel moisture content, though we did not study that variable. Here we can state that the general trend observed is that fuels that burned primarily in a smoldering manner in our studies produced aerosols with a large organic carbon mass fraction and low $\kappa$ values. More detailed examination of the influence of biomass chemical composition, relationships of fuel composition to combustion temperatures and emissions during various stages of combustion, and corresponding effects on the hygroscopic properties of smoke are areas for further study.

Acknowledgements. We acknowledge funding from the Joint Fire Science Program under Project JFSP 05-3-1-06. The FLAME studies were also supported by the National Park Service under contract J2350-07-5181. CMC thanks Jenny Hand and Derek Day for useful discussions during the preparation of this manuscript. We thank Wei-Min Hao and Cyle Wold for their key roles in organizing the FLAME study. We thank all supporting members of the FLAME-II team, particularly staff at the USDA Forest Service Fire Sciences Laboratory in Missoula. We thank the IMPROVE team at UC Davis for aerosol composition measurements. We thank Mike Chandler, Joey Chong, Eric Garrell, Grizelle Gonzales, Sue Grace, Jennifer Hinkley, Randi Jant, Sheah Mucci, Rachael Moore, Robert Olson, Kenneth Outcalt, Jim Reardon, Kevin Robertson, Pauline Spain, and David Weise for collecting the fuel samples for the project.

Edited by: A. Chen

\section{References}

Bond, T. C. and Bergstrom, R. W.: Light absorption by carbonaceous particles: An investigative review, Aerosol Sci. Technol., 40, 27-67, 2006.

Bowman, D., Balch, J. K., Artaxo, P., Bond, W. J., Carlson, J. M., Cochrane, M. A., D'Antonio, C. M., DeFries, R. S., Doyle, J. C., Harrison, S. P., Johnston, F. H., Keeley, J. E., Krawchuk, M. A., Kull, C. A., Marston, J. B., Moritz, M. A., Prentice, I. C., Roos, C. I., Scott, A. C., Swetnam, T. W., van der Werf, G. R., and Pyne, S. J.: Fire in the Earth System, Science, 324, 481-484, 2009.
Brechtel, F. J. and Kreidenweis, S. M.: Predicting particle critical supersaturation from hygroscopic growth measurements in the humidified TDMA. Part II: Laboratory and ambient studies, J. Atmos. Sci., 57, 1872-1887, 2000.

Carrico, C. M., Kreidenweis, S. M., Malm, W. C., Day, D. E., Lee, T., Carrillo, J., McMeeking, G. R., and Collett, J. L.: Hygroscopic growth behavior of a carbon-dominated aerosol in Yosemite National Park, Atmos. Environ., 39, 1394-1404, 2005.

Carrico, C. M., Petters, M. D., Kreidenweis, S. M., Collett, J. L., Engling, G., and Malm, W. C.: Aerosol hygroscopicity and cloud droplet activation of extracts of filters from biomass burning experiments, J. Geophys. Res., 113, D08206, doi:10.1029/2007JD009274, 2008.

Chakrabarty, R. K., Moosmuller, H., Garro, M. A., Arnott, W. P., Walker, J., Susott, R. A., Babbitt, R. E., Wold, C. E., Lincoln, E. N., and Hao, W. M.: Emissions from the laboratory combustion of wildland fuels: Particle morphology and size, J. Geophys. Res., 111, D07204, doi:07210.01029/02005JD006659, 2006.

Chow, J. C., Watson, J. G., Pritchett, L. C., Pierson, W. R., Frazier, C. A., and Purcell, R. G.: The DRI thermal/optical reflectance carbon analysis system: Description, evaluation and applications in US air quality studies, Atmos. Environ., 27A, 1185-1201, 1993.

Christian, T. J., Kleiss, B., Yokelson, R. J., Holzinger, R., Crutzen, P. J., Hao, W. M., Saharjo, B. H., and Ward, D. E.: Comprehensive laboratory measurements of biomass-burning emissions: 1 . Emissions from Indonesian, African, and other fuels, J. Geophys. Res., 108, 4719, doi:4710.1029/2003JD003704, 2003.

Christian, T. J., Kleiss, B., Yokelson, R. J., Holzinger, R., Crutzen, P. J., Hao, W. M., Shirai, T., and Blake, D. R.: Comprehensive laboratory measurements of biomass-burning emissions: 2. First intercomparison of open-path FTIR, PTRMS, and GC- MS/FID/ECD, J. Geophys. Res., 109, D02311, doi:10.1029/2003JD003874, 2004.

Cocker, D. R., Whitlock, N. E., Flagan, R. C., and Seinfeld, J. H.: Hygroscopic properties of Pasadena, California aerosol, Aerosol Sci. Technol., 35, 637-647, 2001.

Day, D. E., Hand, J. L., Carrico, C. M., Engling, G., and Malm, W. C.: Humidification factors from laboratory studies of fresh smoke from biomass fuels, J. Geophys. Res., 111, D22202, doi:22210.21029/22006JD007221, 2006.

Dinar, E., Taraniuk, I., Graber, E. R., Anttila, T., Mentel, T. F., and Rudich, Y.: Hygroscopic growth of atmospheric and model humic-like substances, J. Geophys. Res., 112, D05211, doi:05210.01029/02006JD007442, 2007.

Engling, G., Herckes, P., Kreidenweis, S. M., Malm, W. C., and Collett, J. L.: Composition of the fine organic aerosol in Yosemite National Park during the 2002 Yosemite Aerosol Characterization Study, Atmos. Environ., 40, 2959-2972, 2006.

Garland, R. M., Ravishankara, A. R., Lovejoy, E. R., Tolbert, M. A., and Baynard, T.: Parameterization for the relative humidity dependence of light extinction: Organicammonium sulfate aerosol, J. Geophys. Res., 112, D19303, doi:10.1029/2006JD008179, 2007.

George, I. J., Vlasenko, A., Slowik, J. G., Broekhuizen, K., and Abbatt, J. P. D.: Heterogeneous oxidation of saturated organic aerosols by hydroxyl radicals: uptake kinetics, condensed-phase products, and particle size change, Atmos. Chem. Phys., 7, 4187-4201, doi:10.5194/acp-7-4187-2007, 2007. 
George, I. J., Slowik, J., and Abbatt, J. P. D.: Chemical aging of ambient organic aerosol from heterogeneous reaction with hydroxyl radicals, Geophys. Res. Letts., 35, L13811, doi:13810.11029/12008GL033884, 2008.

George, I. J., Chang, R. Y. W., Danov, V., Vlasenko, A., and Abbatt, J. P. D.: Modification of cloud condensation nucleus activity of organic aerosols by hydroxyl radical heterogeneous oxidation, Atmos. Environ., 43, 5038-5045, 2009.

Hand, J. L., Malm, W. C., Laskin, A., Day, D., Lee, T., Wang, C., Carrico, C., Carrillo, J., Cowin, J. P., Collett, J., and Iedema, M. J.: Optical, physical, and chemical properties of tar balls observed during the Yosemite Aerosol Characterization Study, J. Geophys. Res., 110, D21210, doi:10.1029/2004JD005728, 2005.

Hand, J. L., Day, D. E., McMeeking, G. M., Levin, E. J. T., Carrico, C. M., Kreidenweis, S. M., Malm, W. C., Laskin, A., and Desyaterik, Y.: Measured and modeled humidification factors of fresh smoke particles from biomass burning: role of inorganic constituents, Atmos. Chem. Phys. Discuss., 10, 42254269, doi:10.5194/acpd-10-4225-2010, 2010.

Hopkins, R. J., Lewis, K., Desyaterik, Y., Wang, Z., Tivanski, A. V., Arnott, W. P., Laskin, A., and Gilles, M. K.: Correlations between optical, chemical and physical properties of biomass burn aerosols, Geophys. Res. Letts., 34(18), L18806, doi:10.1029/2007GL030502, 2007.

Kelly, J. T. and Wexler, A. S.: Water uptake by aerosol: Water activity in supersaturated potassium solutions and deliquescence as a function of temperature, Atmos. Environ., 40, 4450-4468, 2006.

Kelly, J. T., Wexler, A. S., Chan, C. K., and Chan, M. N.: Aerosol thermodynamics of potassium salts, double salts, and water content near the eutectic, Atmos. Environ., 42, 3717-3728, 2008.

Kozlowski, T. T. and Pallardy, S. G.: Acclimation and adaptive responses of woody plants to environmental stresses, Botanical Review, 68, 270-334, 2002.

Kreidenweis, S. M., Remer, L. A., Bruintjes, R., and Dubovik, O.: Smoke aerosol from biomass burning in Mexico: Hygroscopic smoke optical model, J. Geophys. Res., 106, 4831-4844, 2001.

Lerdau, M., Litvak, M., and Monson, R.: Plant-Chemical Defense - Monoterpenes And The Growth-Differentiation Balance Hypothesis, Trends In Ecology \& Evolution, 9, 58-61, 1994.

Levin, E. J. T., McMeeking, G. R., Carrico, C. M., Mack, L., Kreidenweis, S. M., Wold, C. E., Moosmueller, H., Arnott, W. P., Hao, W. M., Collett, J. L., and Malm, W. C.: Biomass burning smoke aerosol properties measured during FLAME 2, J. Geophys. Res., doi:10.1029/2009JD013601, in press, 2010.

Lewis, K. A., Arnott, W. P., Moosmüller, H., Chakrabarty, R. K., Carrico, C. M., Kreidenweis, S. M., Day, D. E., Malm, W. C., Laskin, A., Jimenez, J. L., Ulbrich, I. M., Huffman, J. A., Onasch, T. B., Trimborn, A., Liu, L., and Mishchenko, M. I.: Reduction in biomass burning aerosol light absorption upon humidification: roles of inorganically-induced hygroscopicity, particle collapse, and photoacoustic heat and mass transfer, Atmos. Chem. Phys., 9, 8949-8966, doi:10.5194/acp-9-8949-2009, 2009.

Li, J., Pósfai, M., Hobbs, P. V., and Buseck, P. R.: Individual aerosol particles from biomass burning in southern Africa: 2. Compositions and aging of inorganic particles, J. Geophys. Res., 108(D13), 8484, doi:10.1029/2002JD002310, 2003.

Lide, D. R.: CRC Handbook of Chemistry and Physics, 86th ed., CRC Press, Boca Raton, FL, 2005.
Malm, W. C., Schichtel, B. A., Pitchford, M. L., Ashbaugh, L. L., and Eldred, R. A.: Spatial and monthly trends in speciated fine particle concentration in the United States, J. Geophys. Res., 109, D03306, doi:03310.01029/02003JD003739, 2004.

Malm, W. C., Day, D. E., Kreidenweis, S. M., Collett, J. L., Carrico, C., McMeeking, G., and Lee, T.: Hygroscopic properties of an organic-laden aerosol, Atmos. Environ., 39, 4969-4982, 2005.

McMeeking, G. R., Kreidenweis, S. M., Lunden, M., Carrillo, J., Carrico, C. M., Lee, T., Herckes, P., Engling, G., Day, D. E., Hand, J., Brown, N., Malm, W. C., and Collett, J. L.: Smokeimpacted regional haze in California during the summer of 2002, Agr. Forest Meteorol., 137, 25-42, 2006.

McMeeking, G. R., Kreidenweis, S. M., Baker, S., Carrico, C. M., Chow, J. C., Collett, J. L., Hao, W. M., Holden, A. S., Kirchstetter, T. W., Malm, W. C., Moosmuller, H., Sullivan, A. P., and Wold, C. E.: Emissions of trace gases and aerosols during the open combustion of biomass in the laboratory, J. Geophys. Res., 114, D19210, doi:10.1029/2009JD011836, 2009.

Moore, R. H., and Raymond, T. M.: HTDMA analysis of multicomponent dicarboxylic acid aerosols with comparison to UNIFAC and ZSR, J. Geophys. Res., 113, D04206, doi:10.1029/2007JD008660, 2008.

Naeher, L. P., Brauer, M., Lipsett, M., Zelikoff, J. T., Simpson, C. D., Koenig, J. Q., and Smith, K. R.: Woodsmoke health effects: A review, Inhal Toxicol, 19, 67-106, 2007.

Park, R. J., Jacob, D. J., and Logan, J. A.: Fire and biofuel contributions to annual mean aerosol mass concentrations in the United States, Atmos. Environ., 41, 7389-7400, 2007.

Petters, M. D., Prenni, A. J., Kreidenweis, S. M., DeMott, P. J., Matsunaga, A., Lim, Y. B., and Ziemann, P. J.: Chemical aging and the hydrophobic-to-hydrophilic conversion of carbonaceous aerosol, Geophys. Res. Lett., 33, L24806, doi:24810.21029/22006GL027249, 2006.

Petters, M. D. and Kreidenweis, S. M.: A single parameter representation of hygroscopic growth and cloud condensation nucleus activity, Atmos. Chem. Phys., 7, 1961-1971, doi:10.5194/acp-71961-2007, 2007.

Petters, M. D., Carrico, C. M., Kreidenweis, S. M., Prenni, A. J., DeMott, P. J., Collett, J. L., and Moosmuller, H.: Cloud condensation nucleation activity of biomass burning aerosol, J. Geophys. Res., 114, D22205, doi:10.1029/2009JD012353, 2009a.

Petters, M. D., Parsons, M. T., Prenni, A. J., DeMott, P. J., Kreidenweis, S. M., Carrico, C. M., Sullivan, A. P., McMeeking, G. R., Levin, E., Wold, C. E., Collett, J. L., and Moosmuller, H.: Ice nuclei emissions from biomass burning, J. Geophys. Res., 114, D07209, doi:10.1029/2008JD011532, 2009b.

Prenni, A. J., DeMott, P. J., and Kreidenweis, S. M.: Water uptake of internally mixed particles containing ammonium sulfate and dicarboxylic acids, Atmos. Environ., 37, 4243-4251, 2003.

Rader, D. J. and McMurry, P. H.: Application of the tandem differential mobility analyzer to studies of droplet growth or evaporation, J. Aerosol. Sci., 17, 771-787, 1986.

Ramanathan, V., Crutzen, P. J., Lelieveld, J., Mitra, A. P., Althausen, D., Anderson, J., Andreae, M. O., Cantrell, W., Cass, G. R., Chung, C. E., Clarke, A. D., Coakley, J. A., Collins, W. D., Conant, W. C., Dulac, F., Heintzenberg, J., Heymsfield, A. J., Holben, B., Howell, S., Hudson, J., Jayaraman, A., Kiehl, J. T., Krishnamurti, T. N., Lubin, D., McFarquhar, G., Novakov, T., Ogren, J. A., Podgorny, I. A., Prather, K., Priestley, K., Prospero, 
J. M., Quinn, P. K., Rajeev, K., Rasch, P., Rupert, S., Sadourny, R., Satheesh, S. K., Shaw, G. E., Sheridan, P., and Valero, F. P. J.: Indian Ocean Experiment: An integrated analysis of the climate forcing and effects of the great Indo-Asian haze, J. Geophys. Res., 106, 28371-28398, 2001.

Reid, J. S., Koppmann, R., Eck, T. F., and Eleuterio, D. P.: A review of biomass burning emissions part II: intensive physical properties of biomass burning particles, Atmos. Chem. Phys., 5, 799825, doi:10.5194/acp-5-799-2005, 2005.

Reutter, P., Su, H., Trentmann, J., Simmel, M., Rose, D., Gunthe, S. S., Wernli, H., Andreae, M. O., and Pöschl, U.: Aerosoland updraft-limited regimes of cloud droplet formation: influence of particle number, size and hygroscopicity on the activation of cloud condensation nuclei (CCN), Atmos. Chem. Phys., 9, 7067-7080, doi:10.5194/acp-9-7067-2009, 2009.

Rissler, J., Vestin, A., Swietlicki, E., Fisch, G., Zhou, J., Artaxo, P., and Andreae, M. O.: Size distribution and hygroscopic properties of aerosol particles from dry-season biomass burning in Amazonia, Atmos. Chem. Phys., 6, 471-491, doi:10.5194/acp6-471-2006, 2006.

Semeniuk, T. A., Wise, M. E., Martin, S. T., Russell, L. M., and Buseck, P. R.: Hygroscopic behavior of aerosol particles from biomass fires using environmental transmission electron microscopy, J. Atmos. Chem., 56, 259-273, 2007.

Simoneit, B. R. T., Rogge, W. F., Mazurek, M. A., Standley, L. J., Hildemann, L. M., and Cass, G. R.: Lignin pyrolysis products, lignans, and resin acids as specific tracers of plant classes in emissions from biomass combustion, Environ. Sci. Technol., 27, 2533-2541, 1993.

Spracklen, D. V., Logan, J. A., Mickley, L. J., Park, R. J., Yevich, R., Westerling, A. L., and Jaffe, D. A.: Wildfires drive interannual variability of organic carbon aerosol in the western US in summer, Geophys. Res. Lett., 34, L16816, doi:10.1029/2007GL030037, 2007.
Stolzenburg, M. R. and McMurry, P. H.: TDMAFIT User's Manual, Particle Technology Laboratory, Department of Mechanical Engineering, University of Minnesota, Minneapolis, MNPTL Publication No. 653, 1988.

Sullivan, A. P., Holden, A. S., Patterson, L. A., McMeeking, G. R., Kreidenweis, S. M., Malm, W. C., Hao, W. M., Wold, C. E., and Collett, J. L.: A method for smoke marker measurements and its potential application for determining the contribution of biomass burning from wildfires and prescribed fires to ambient $\mathrm{PM}_{2.5}$ organic carbon, J. Geophys. Res., 113, L16816, doi:10.1029/2008JD010216, 2008.

Swietlicki, E., Zhou, J. C., Covert, D. S., Hameri, K., Busch, B., Vakeva, M., Dusek, U., Berg, O. H., Wiedensohler, A., Aalto, P., Makela, J., Martinsson, B. G., Papaspiropoulos, G., Mentes, B., Frank, G., and Stratmann, F.: Hygroscopic properties of aerosol particles in the northeastern Atlantic during ACE-2, Tellus, 52, 201-227, 2000.

Tang, I. N.: Deliquescence properties and particle size change of hygroscopic aerosols, in: Generation of Aerosols, edited by: Willeke, K., Ann Arbor Science Publishers, Ann Arbor, MI, 153-167, 1980.

Tang, I. N. and Munkelwitz, H. R.: Composition and TemperatureDependence of the Deliquescence Properties of Hygroscopic Aerosols, Atmos. Environ., 27, 467-473, 1993.

Tang, I. N.: Thermodynamic and optical properties of mixedsalt aerosols of atmospheric importance, J. Geophys. Res., 102, 1883-1893, 1997.

Zhou, J. C., Swietlicki, E., Hansson, H. C., and Artaxo, P.: Submicrometer aerosol particle size distribution and hygroscopic growth measured in the Amazon rain forest during the wet season, J. Geophys. Res., 107, 8055, doi:8010.1029/2000JD000203, 2002. 